$$
\text { ANL-7134 327 }
$$

ANL-7134

Argonne Rational Laboratom

THE PROCESSING OF ROCK DEBRIS FOR TRANSPLUTONIUM ELEMENTS PRODUCED BY UNDERGROUND NUCLEAR DETONATIONS

by

E. P. Horwitz, C. A. A. Bloomquist, H. W. Harvey, and J. C. Hah 


\section{DISCLAIMER}

This report was prepared as an account of work sponsored by an agency of the United States Government. Neither the United States Government nor any agency Thereof, nor any of their employees, makes any warranty, express or implied, or assumes any legal liability or responsibility for the accuracy, completeness, or usefulness of any information, apparatus, product, or process disclosed, or represents that its use would not infringe privately owned rights. Reference herein to any specific commercial product, process, or service by trade name, trademark, manufacturer, or otherwise does not necessarily constitute or imply its endorsement, recommendation, or favoring by the United States Government or any agency thereof. The views and opinions of authors expressed herein do not necessarily state or reflect those of the United States Government or any agency thereof. 


\section{DISCLAIMER}

Portions of this document may be illegible in electronic image products. Images are produced from the best available original document. 


\section{LEGAL NOTICE}

This report was prepared as an account of Government sponsored work. Nelther the United States, nor the Commission, nor any person acting on behalf of the Commission:

A. Makes any warranty or representation, expressed or implied, with respect to the accuracy, completeness, or usefulness of the information contained in this report, or that the use of any information, apparatus, method, or process disclosed in this report may not infringe privately owned rights; or

B. Assumes any liabilities with respect to the use of, or for damages resulting from the use of any information, apparatus, method, or process disclosed in this report.

As used in the above, "person acting on behalf of the Commission" includes any employee or contractor of the Commission, or employee of such contractor, to the extent that such employee or contractor of the Commission, or employee of such contractor prepares, disseminates, or provides access to, any information pursuant to his employment or contract with the Commission, or his employment with such contractor.

Printed in USA. Price $\$ 2.00$. Available from the Clearinghouse for Federal Scientific and Technical Information, National Bureau of Standards,

U. S. Department of Commerce, Springfield, Virginia 22151 
ANL-7134

Nuclear Explosions--

Peaceful Applications

(TID-4500)

AEC Research and

Development Report

ARGONNE NATIONAL LABORATORY

\section{CFSTI PRICES}

9700 South Cass Avenue

Argonne, Illinois 60439

H.C. $\$ 2.00 ; \mathrm{MN} \cdot .50$

THE PROCESSING OF ROCK DEBRIS

FOR TRANSPLUTONIUM ELEMENTS PRODUCED BY

UNDERGROUND NUCLEAR DETONATIONS

by

E. P. Horwitz, C. A. A. Bloomquist,

H. W. Harvey, and J. C. Hoh

Chemistry Division

\section{LEGAL NOTICE}

This report was prepared as an account of Government sponeored

A. Makes Commission, nor any person acting on behnif of the work. Neither the United

racy, completeness or ty or representation, expressed or implied, Commission:

of any information, or usefulness of the information contained in this roport to the accu-

privately owned r ingaratus, method, or process disclosed in this report, or that the use

B. A whed rights; or

Be of any information, appars with respect to the use of, or for damages resuling from

As used in the above, "person acting or process disclosed in this report.

ployee or contractor of the Commission, or behalf of the Commission" includes any em

such employee or contractor of the Com, or employee of such contractor, to the exyy em-

wissentes, or provides access to any, or employee of such contracter prent that

with the Commission, or his employment information pursuant to his employment prepa fes

rebruary 1966

RELEASED FOR ANNOUNCEMENT

IN NUCIEAR SCIENCE ABSTRACTS

Operated by The University of Chicago

under

Contract W-31-109-eng-38

with the

U. S. Atomic Energy Commission 
TAB LE OF CONTENTS

Page

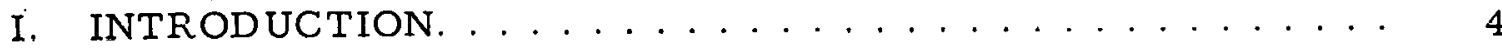

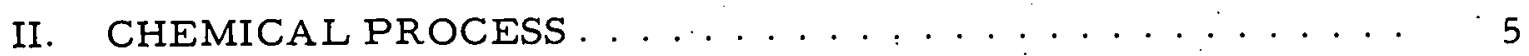

A. General Processing Approach . . . . . . . . 5

B. Equipment and Operating Techniques .......... 7

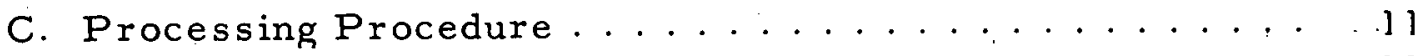

l. Dissolution of the Rock ....................... 11

2. Feed Preparation .............................. 14

3. Liquid-Liquid Extraction ................. 16

4. Final Purification of the Transplutonium Elements . . 17

5. Final Purification of the Plutonium ............ 18

III. SUMMARY . . . . . . . . . . . . . . . . . 19

APPENDIXES

A. Equipment and Materials............... 20

B. Reagent Purification and Preparation . . . . . . . . 22

ACKNOW LEDGMENT . . . . . . . . . . . . . . . . . . . 24

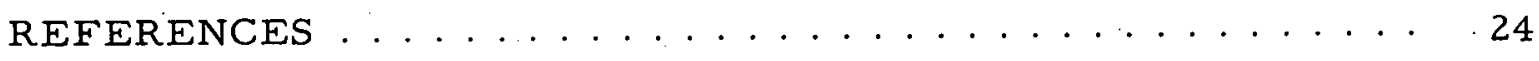




\section{LIST OF FIGURES}

No.

Title

Page

1. Inside View of Containment Box 1 Showing Equipment for

Dissolution and Precipitation Steps ............ 8

2. Inside View of Containment Box 2 Showing Apparatus for

Liquid-Liquid Extraction Step. . . . . . . . . . 8

3. Back of Containment Boxes Showing Transfer Ports,

Centrifuge, Reagent Storage Bottles, and Filter Systems... . y

4. View of Outside of Cave Showing Controls for Remotely

Operated Equipment.................. 9

5. Motorized Centrifuge Bottle Loading Device.......... 10

6. Flowsheet for Rock Dissolution and Feed Preparation . . . . . 12

7. Flowsheet for Liquid-Liquid Extraction Procedure. . . . . . 12

8. Flowsheet for the Final Purification of the Transplutonium

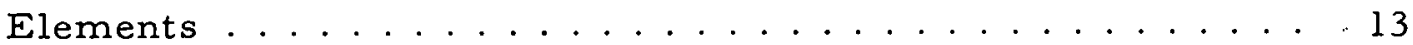

9. Flowsheet for the Plutonium Purification........... 13 


\title{
THE PROCESSING OF ROCK DEBRIS \\ FOR TRANSPLUTONIUM ELEMENTS PRODUCED BY UNDERGROUND NUCLEAR DETONATIONS
}

by

\author{
E. P. Horwitz, C. A. A. Bloomquist, \\ H. W. Harvey, and J. C. Hoh
}

\section{INTRODUCTION}

One purpose of the Plowshare program is to produce very heavy isotopes of the transplutonium elements by exposing uranium or other targets' to the intense neutron fluxes generated in underground thermonuclear explosions. ${ }^{1-4}$ This technique can create isotopes of the transplutonium elemerits that are not readily produced in high-flux reactors. In addition, the method holds promise for producing elements beyond atomic number 103. The most successful device tested thus far (exploded in October 1964) produced isotopes through mass 257 and element $100 .^{3}$

The nuclear devices, which are designed by the Los Alamos Scientific Laboratory and the Lawrence Radiation Laboratory at Livermore, California, are detonated underground at the Atomic Energy Commission's Nevada test site. The explosion of the device distributes the transplutonium elements and fission products throughout large amounts of fused rock. Samples of rock containing radioactive debris are obtained by drilling to the appropriate depth and sorting the resultant borings according to gamma activity. The samples containing the highest activities are dried, crushed, and pulverized, and distributed to a number of laboratories for processing and radiochemical analysis. (The laboratories participating in the analysis of the rock debris are: Argonne National Laboratory, Lawrence Radiation Laboratory at Livermore and Berkeley, and Los Alamos Scientific Laboratory.)

This report describes the chemical process used at Argonne National Laboratory for the recovery of the transplutonium elements and plutonium from l-kg batches of rock debris from underground nuclear explosions. The quantities of transplutonium elements present in $\mathrm{l} \mathrm{kg}$ of sample are extremely minute. For example, the most abundant transplutonium element may be present to the extent of only one part in $10^{12}$ parts of rock. Consequently, the processing problem is one of isolating in high yield minute quantities of the transplutonium elements from the gross constituents of the rock and from fission products. A minimum expenditure of time for processing is also important because of the decay of short-lived isotopes. 
Because of the high gamma activity associated with $1 \mathrm{~kg}$ of rock debris $(200-1,000 \mathrm{R} / \mathrm{hr}$ at 2 in.), the initial processing of large quantities of rock must be performed in a high-level cave by remote control. The special equipment and apparatus used for processing under these conditions are shown and described in this report.

\section{CHEMICAL PROCESS}

\section{A. General Processing Approach}

The rock samples are essentially aluminum silicates containing small quantities of calcium, iron, and magnesium. The $\mathrm{SiO}_{2}$ and $\mathrm{Al}_{2} \mathrm{O}_{3}$ contents are in the ranges of 60 to $70 \%$ and $10-20 \%$, respectively. The $\mathrm{CaO}, \mathrm{Fe}_{2} \mathrm{O}_{3}$, and $\mathrm{MgO}$ are all in the 0 to $5 \%$ range.

The pulverized rock is extremely reactive towards conc (28M) HF. This reactivity is probably due, in part, to the amorphous condition of the samples as a result of the fusion of the rock by the heat of the underground nuclear explosion. Consequently, conc HF affords an easy method of removing the silica. The gross cationic constituents, as well as the small quantities of transuranium and lanthanide ions, are left in a water-insoluble fluoride residue. The fluoride residue is readily converted into a concentrated chloride or nitrate salt solution by methathesis and acid-dissolution steps. This approach rapidly dissolves all the cations from the rock except those that are soluble in $\mathrm{HF}, \mathrm{e} . \mathrm{g} ., \mathrm{Zr}, \mathrm{Hf}, \mathrm{Nb}, \mathrm{Ta}, \mathrm{M} \odot$, and $\mathrm{W}$.

At this stage, an organic extractant is selected.to remove the transplutonium(III) and plutonium(IV) ions from the resultant $\mathrm{Al}, \mathrm{Ca}, \mathrm{Mg}$, and Fe solution. Organic compounds such as HDEHP and HEH[ $\phi$ P] extract transplutonium(III) ions from dilute acid solutions; however, they do not have large $(>100)$ separation factors between, for example, $\mathrm{Cm}$ (III) and $\mathrm{Al}$ (III) or $\mathrm{Ca}$ (II). TBP and high-molecular-weight tertiary amines are known to extract transplutonium(III) and $\mathrm{Pu}(\mathrm{IV})$ ions. from concentrated $\mathrm{Al}$, $\mathrm{Ca}$, and $\mathrm{Mg}$ nitrate solutions and thus could be used for this purpose in the process. However, on the bases of a recent study, ${ }^{5}$ a high-molecularweight quaternary ammonium compound, Aliquat-336 nitrate*, was selected as the extractant. High $\mathrm{K}_{\mathrm{d}}$ values can be obtained. for Am(III), Cm(III), $\mathrm{Cf}(\mathrm{III})$, and Es(III) by using a $0.4 \mathrm{~F}$ xylene solution of the extractant and $\mathrm{Li}, \mathrm{Mg}, \mathrm{Ca}$, and $\mathrm{Al}$ nitrate solutions in the range of 4 to $8 \underline{\mathrm{N}} \mathrm{NO}_{3}^{-}$and $<0.1 \mathrm{M} \mathrm{H}^{+}$. In addition, separation factors between the transplutonium(III)

*Aliquat-336 nitrate is a quaternary ammonium nitrate with the following structure:

$$
\left[\begin{array}{l}
\mathrm{R} \\
\mathrm{RNCH} \\
\mathrm{R}
\end{array}\right]^{+} \mathrm{NO}_{3}^{-},
$$

where $R$ is a mixture of n-octyl and $n$-decyl. 
ions and $\mathrm{Li}, \mathrm{Mg}, \mathrm{Ca}, \mathrm{Al}$, and $\mathrm{Fe}$ (III) are greater than 103. Concentrated $\mathrm{LiNO}_{3}$ solution is an effective scrubbing agent for additional decontamination. Plutonium(IV) and lanthanide(III) ions are also highly extracted by Aliquat-336 nitrate, whereas certain fission products, such as $\mathrm{Cs}, \mathrm{Sr}$, $\mathrm{Zr}$, and $\mathrm{Nb}$, arc poorly extracted. The transplutonium(III) and lanthanide(III) ions are easily stripped from the amine with $2 \underline{\mathrm{M}} \mathrm{HNO}_{3}$, while $\mathrm{Pu}$ (IV) remains in the organic phase. Adjusting the organic to aqueous phase ratios to $\leqslant l$ during the feed equilibration, and to $\gg l$ during the stripping equilibration, results in a considerable concentration of the transplutonium and lanthanide elements. Plutonium(IV) is stripped from the organic phase with $\mathrm{HClO}_{4 !}$ or $\mathrm{Fe}\left(\mathrm{SO}_{3} \mathrm{NH}_{2}\right)_{i j}$.

At this stage, the transplutonium and lanthanide elements are highly decontaminated from gross constituents, such as $\mathrm{Al}, \mathrm{Ca}, \mathrm{Mg}$, and $\mathrm{Fe}$ and a majority of the fission products. Final purification steps involve well-known radiochemical techniques, which are described in detail in the processing procedure (Section $\mathrm{C}$ below).

The main feature of the above approach is the liquid-liquid extraction scheme. Although the extraction step is simple in concept, its success in actual processing of rock depends on two conditions: first, the selection of the proper $\left[\mathrm{NO}_{3}^{-}\right]$and $\left[\mathrm{H}^{+}\right]$in the feed and the proper amine concentration in the organic phase to obtain the desired recovery of transplutonium elements; and, second, the removal of colloidal and soluble silicic acid from the feed solution.to prevent emulsion and interfacial precipitate formation.

On the basis of the composition of the rock samples, reported $K_{d}$ data, ${ }^{5}$ and small-scale rock-processing experiments, the following conditions were selected for the liquid-liquid extraction step:

Aqueous feed: $\quad \sim 7.5 \underline{N}$ Nitrate Ion $\sim 0.05 \underline{N}$ Hydrogen Ion

Organic phase: $\quad 0.4 \underline{F}$ Aliquat-336 Nitrate in Xylene

Phase ratio $(\mathrm{O} / \mathrm{A}): 0.5$

Using these conditions, $>99 \%$ of the transplutonium(III) ions [and $\mathrm{Pu}$ (III), (IV), and (VI)] can be extracted into the organic phase by two-batch equilibrations of the feed solution. In addition, the se conditions enable one to use, on a kilogram processing scale, simple laboratory separatory funnels for the extraction step. The attainment of the selected. [ $\left.\mathrm{NO}_{3}^{-}\right]$and $\left[\mathrm{H}^{+} \cdot\right.$ ] in the feed solution is achieved by first evaporating the feed solution and then adding conc $\mathrm{NH}_{4} \mathrm{OH}$ and/or basic aluminum nitrate solution.

The silicic acid is removed from the feed solution by digesting the solution for a given period of time to dehydrate the majority of the silicic acid. The remaining soluble silicic acid is precipitated by the addition of 
gelatin solution. ${ }^{6}$ (The gelatin protein and the silicic acid polymer are believed to combine through hydrogen bonding. ${ }^{6}$ ) This technique completely eliminates emulsion and interfacial precipitate formation.

B. Equipment and Operating Techniques

The equipment used for processing the sample by remote control in a high-level cave was designed with simplicity, reliability, and safety as the prime criteria. These criteria are realized in most cases by the use of standard-size laboratory glassware and equipment housed in a containment box. A high degree of reliability is provided by manual operation through master-slave manipulators. Figures 1-5 show the general layout and apparatus employed.

Solid-liquid equilibrations are carried out in l-quart, widemouthed, polyprophylene bottles by means of a motorized, four-station, stirring unit. (This unit is shown in the right foreground of Fig. 1.) The resultant mixtures are separated by centrifugation in an International Size 2 portable centrifuge, which is modified and positioned to open into containment box 1. (See Figs. 1 and 3.) The l-quart bottles are placed directly in the centrifuge shields, after balancing on the pan balance, by means of a specially designed, motorized, bottle-loading device. (See Fig. 5.) (Each widemouthed bottle must be shortened by removing the threaded top to prevent thc bottles from catching on the centrifuge head during centrifugation.) After centrifugation, the supernatant liquid is decanted; consequently, the solid phase does not have to be transferred. Bottle grippers (shown in the left foreground in Fig. 1) are used to manipulate the l-quart bottles during the decantation operation. By means of these techniques, the operators are able to carry out many solid-liquid equilibrations, centrifugations, and decantations with relative ease and rapidity.

Distilled $\mathrm{H}_{2} \mathrm{O}, 3.5 \mathrm{M} \mathrm{NaOH}$, conc $\mathrm{HCl}$, and saturated $\mathrm{H}_{3} \mathrm{BO}_{3}$ can be obtained, in containment box l, at the chemical reagent dispensing station. (The dispensing station can be seen in Fig. 1 on the left side of the containment box.) The distilled $\mathrm{H}_{2} \mathrm{O}$ is piped directly into the highlevel cave. The other reagents are stored behind containment box 1 in large polyethylene bottles with serrated tubulature (see Fig. 3).

Evaporation and digestion operations are carried out in a calibrated 4-liter beaker, located in the left rear of containment box 2 (see Fig. 2 ). The beaker is clamped on trunnions and equipped with a handle for pouring. A hot plate-magnetic stirrer is located underneath the beaker; however, during the pouring of solution from the beaker this apparatus is removed.

The liquid-liquid extraction procedure is performed in 2-liter separatory funnels equipped with Teflon stopcocks. The separatory funnels are modified as shown in Fig. 2. Graduated $800-\mathrm{ml}$ beakers, 


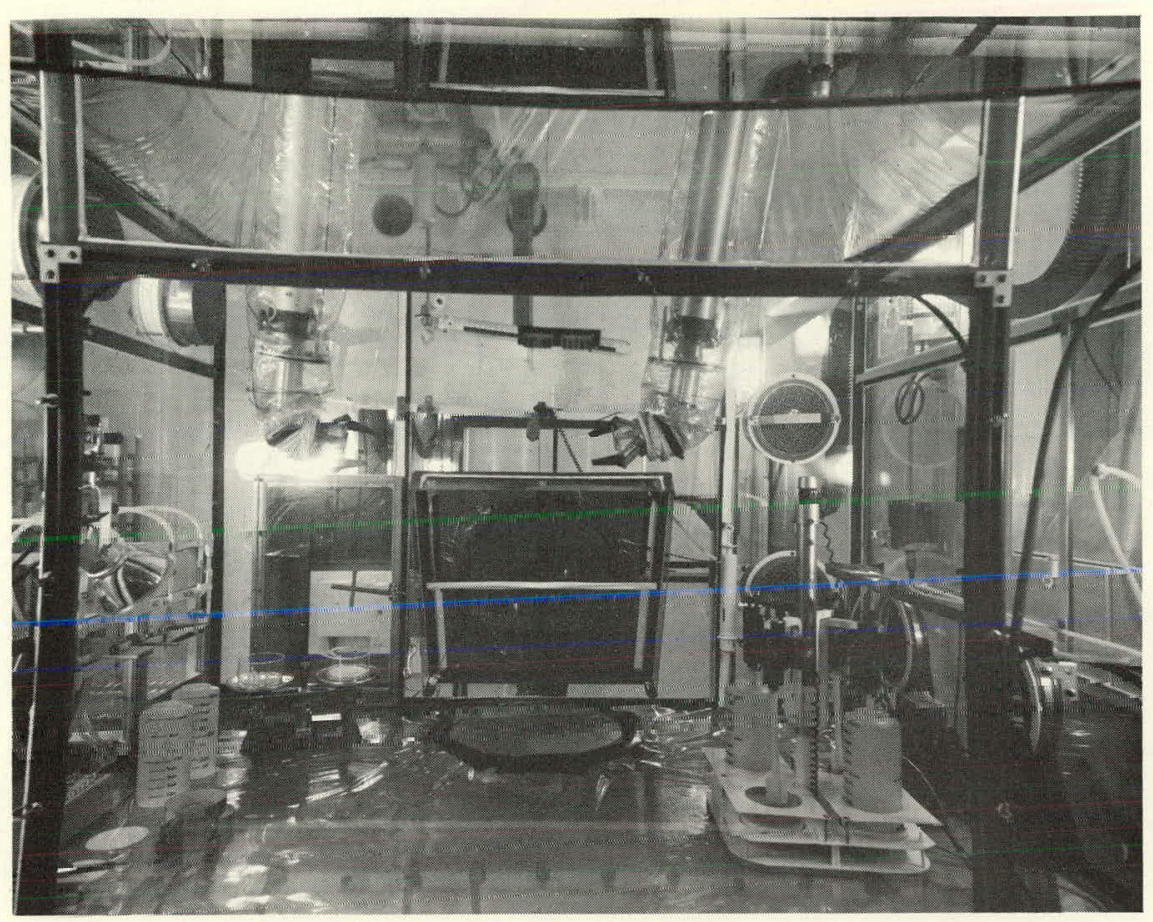

$121-521$

Fig. 1. Inside View of Containment Box l Showing Equipment for Dissolution and Precipitation Steps

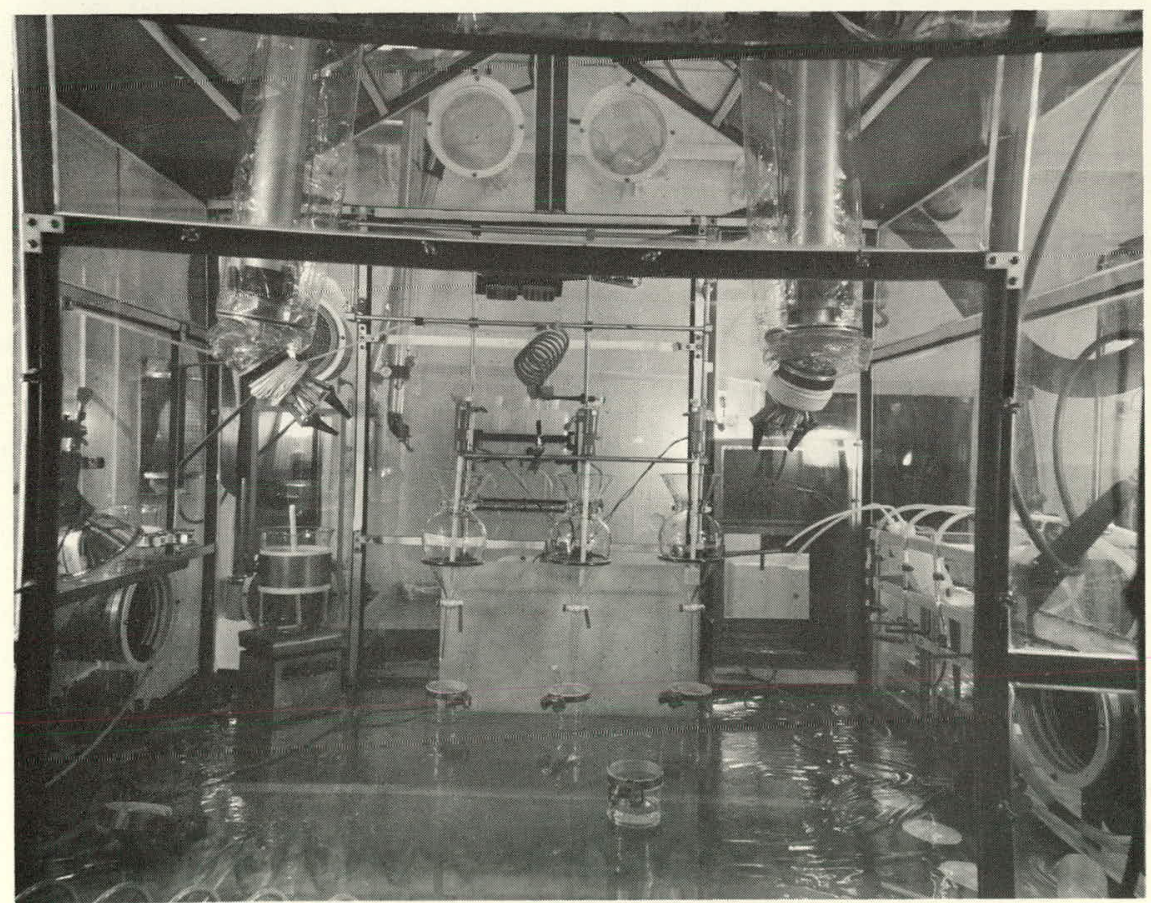

121-522

Fig. 2. Inside View of Containment Box 2 Showing Apparatus for Liquid-Liquid Extraction Step 


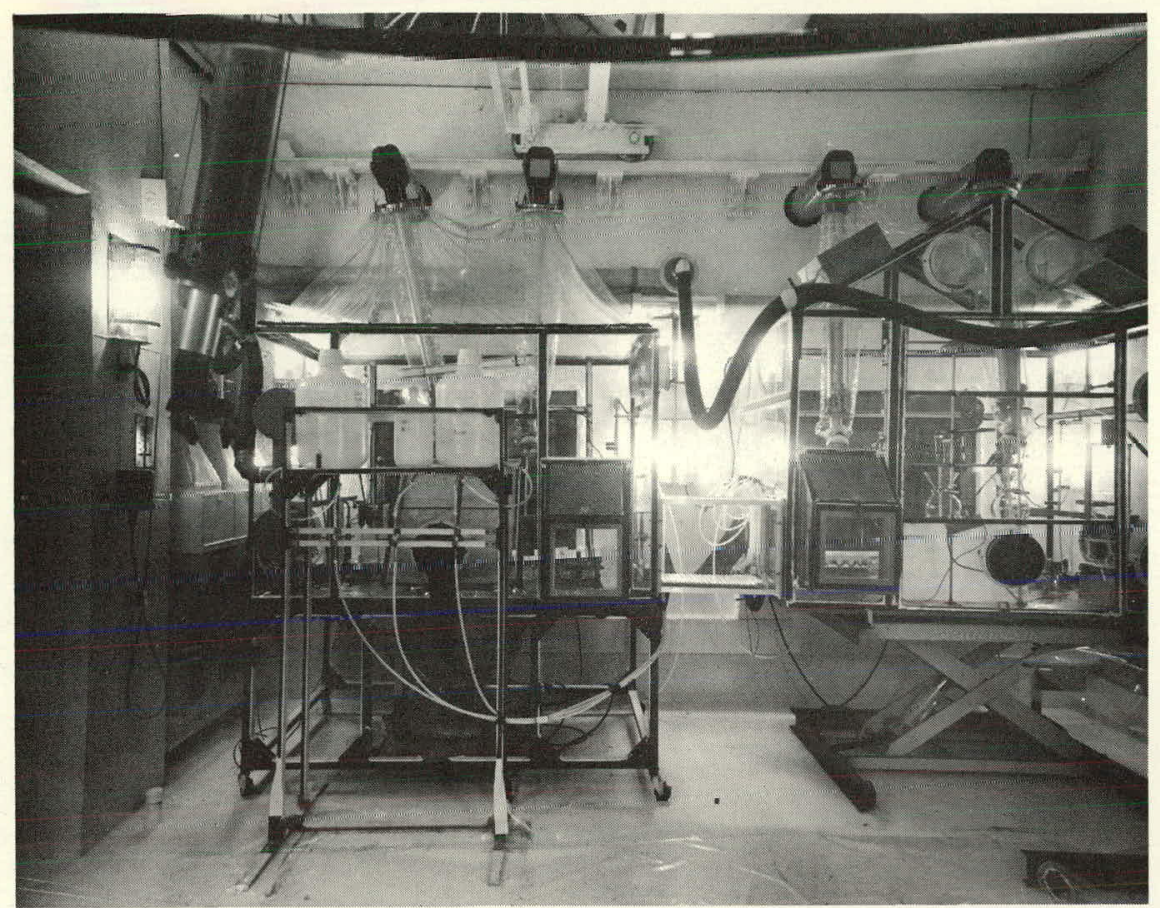

$121-523$

Fig. 3. Back of Containment Boxes Showing Transfer Ports, Centrifuge, Reagent Storage Bottles, and Filter Systems

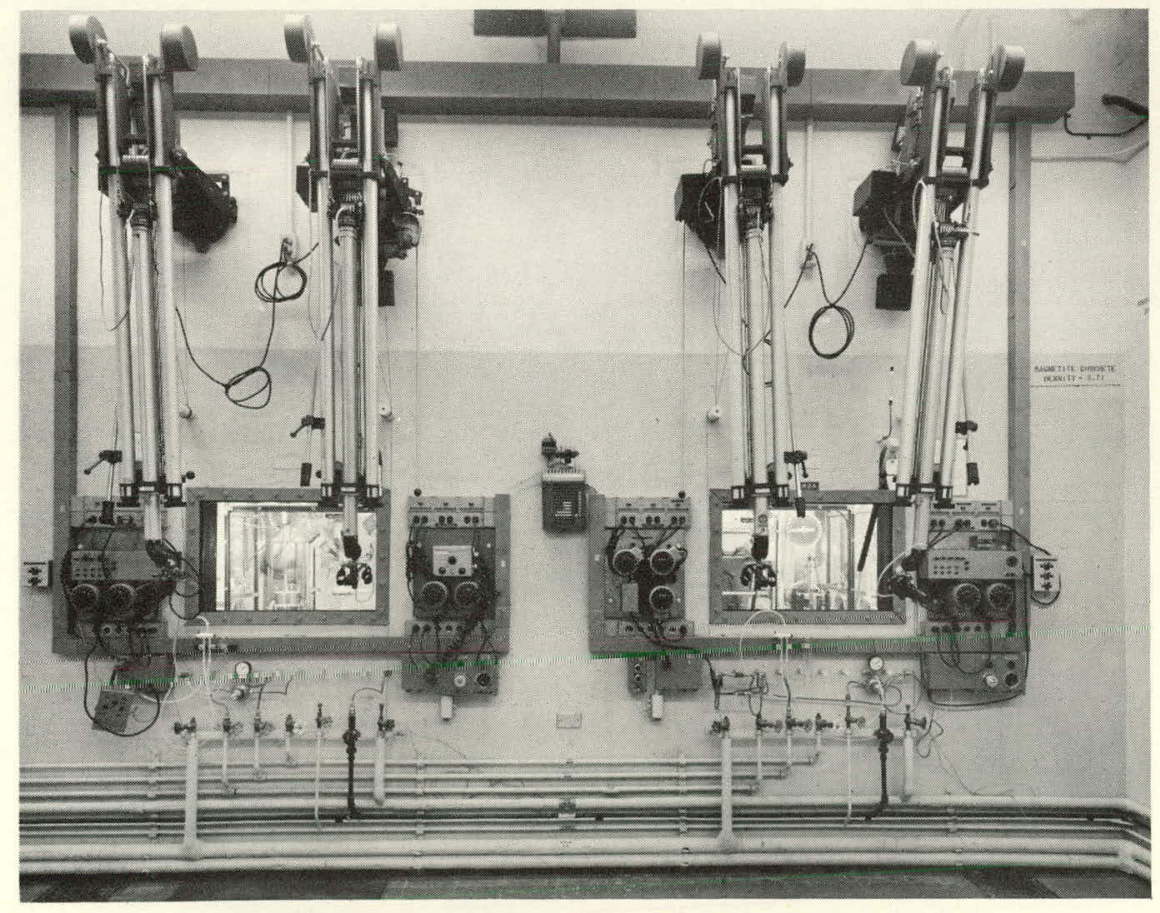

$121-524$

Fig. 4. View of Outside of Cave Showing Controls for Remotely Operated Equipment 


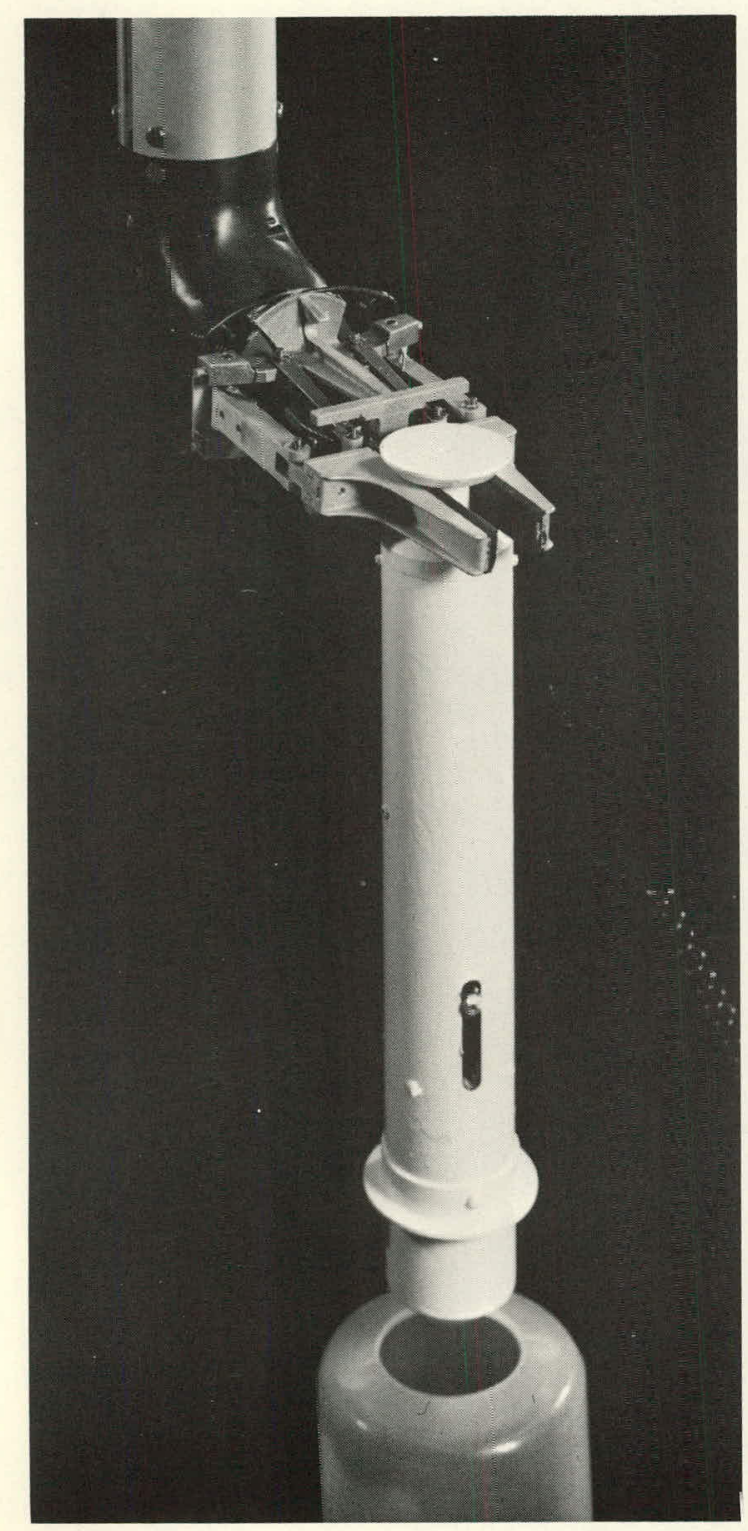

$121-395$

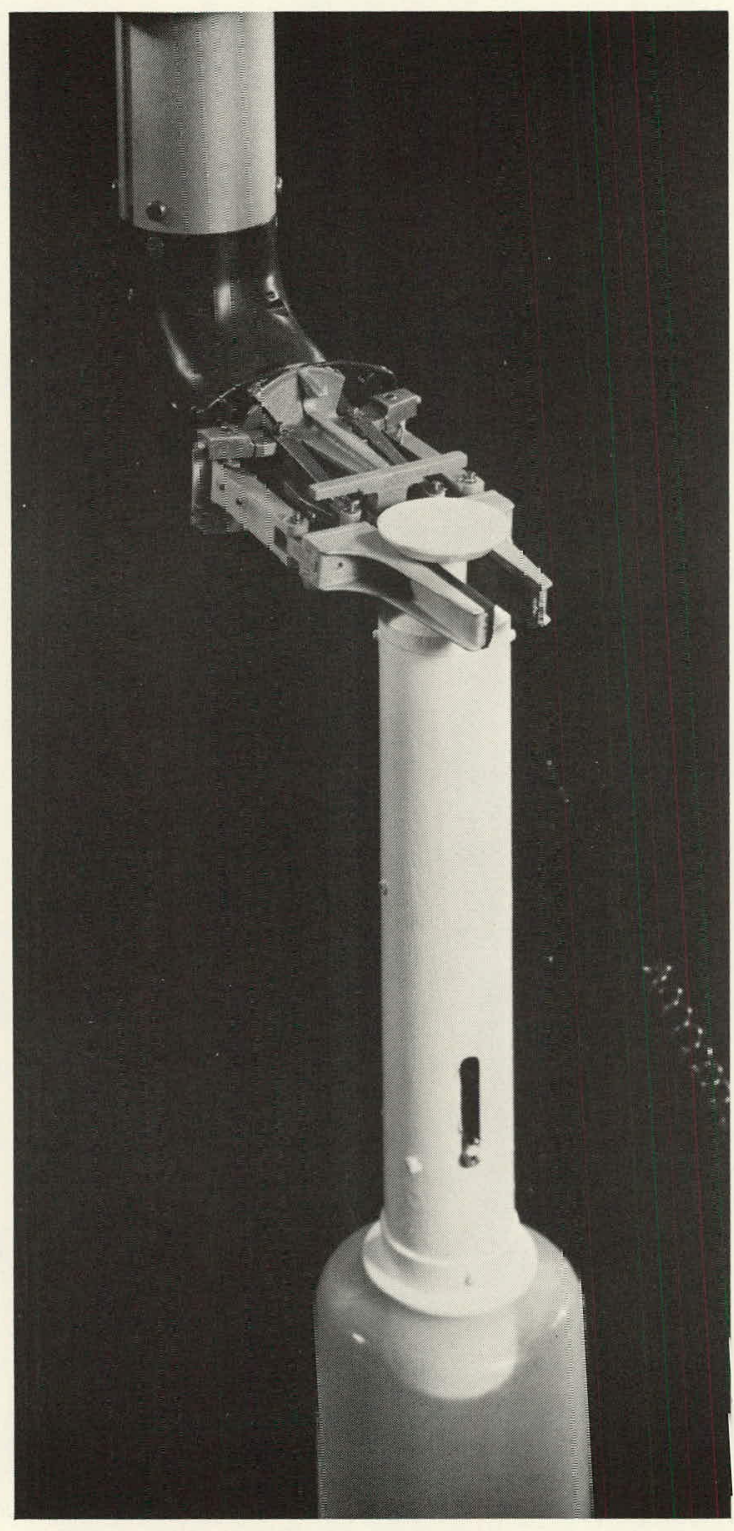

$121-394$

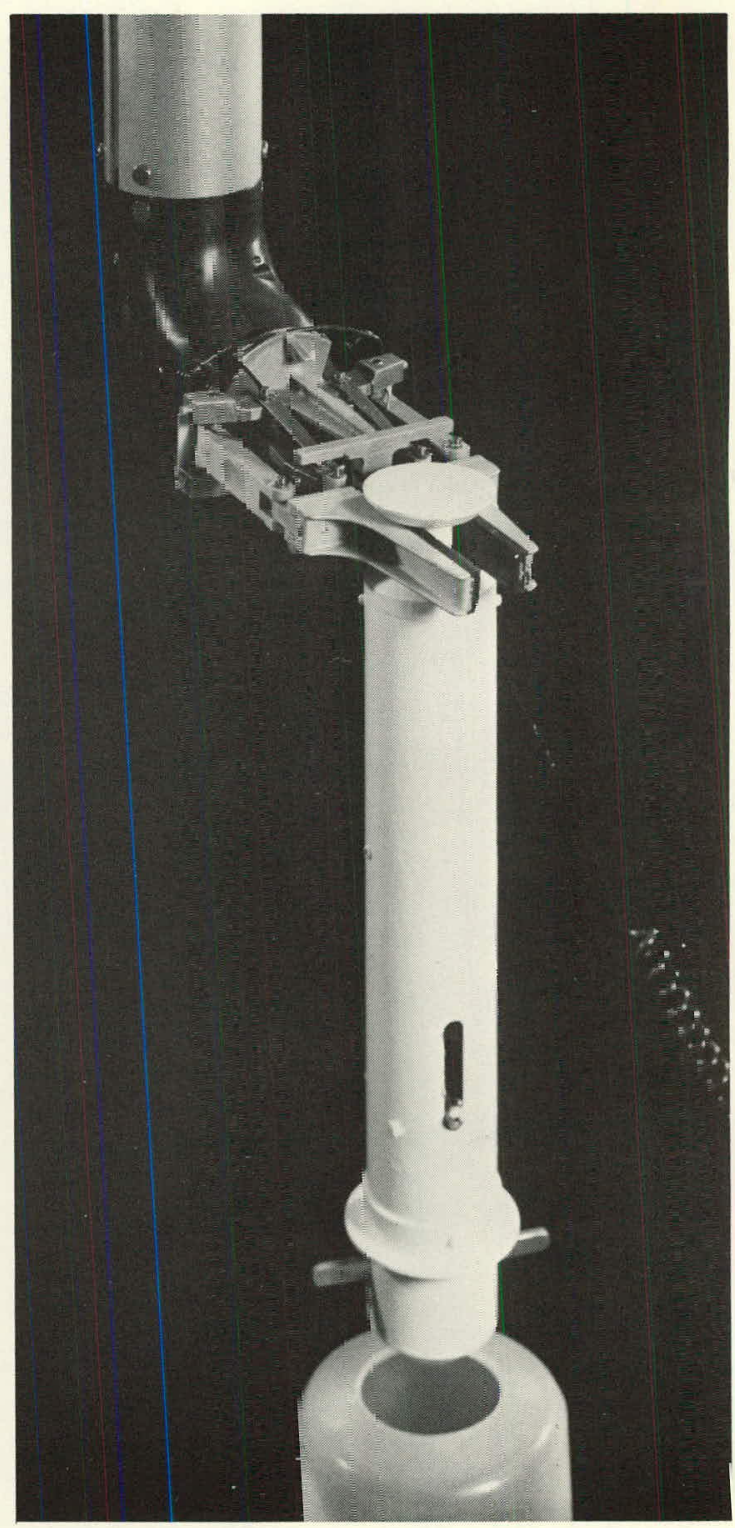

$121-396$

b. Engagec w:th Fingers Extended.

c. Disengag $€$ d with Fingers Extelced. 
which are adapted for easy gripping by the manipulator fingers, are used for collecting and transferring feed scrub and strip solutions.

The special equipment and materials used are listed in Appendix A.

The final processing of the sample is carried out in a hood using primarily standard radiochemical techniques and equipment. Smallscale ( l-15 ml) liquid-liquid extractions are performed in 12 - and $40-\mathrm{ml}$ centrifuge tubes. The phases are equilibrated by means of a vortex mixer, separated with the aid of a.clinicalcentrifuge, and transferred by means of a transfer pipet-syringe arrangement. This technique of mixing and separating phases is very rapid and efficient. Precipitations involving 50-600-ml volumes are performed in large centrifuge bottles (250- and 600-ml capacities). Mixtures are centrifuged in an International Size 2 portable centrifuge. Ion-exchange-column flow rates are adjusted by a regulated air-pressure system.

C. Processing Procedure

The chemical processing procedure is divided into the following six steps:

1. Dissolution of rock

2. Feed preparation

3. Liquid-liquid extraction

4. Final purification of the transplutonium elements

5. Final purification of plutonium

6. Separation of the individual transplutonium elements.

Each step will be individually described below, with the exception of Step 6. The separation of the individual transplutonium ions on a tracer scale using $\alpha$-hydroxyisobutyric acid has been adequately described in other reports. ${ }^{7}$ Flowsheets showing the entire process are presented in Figs. 6-9. Reagent purifications and preparations are presented in Appendix B.

1. Dissolution of the Rock

One $\mathrm{kg}$ of pulverized rock is divided equally between four 1-quart polypropylene bottles. The sample is mixed. with $300 \mathrm{ml}$ of conc $\mathrm{HCl}$ and 2.8 liters of conc HF. Approximately $100 \mathrm{mg}$ of $\mathrm{La}$ (III) is added with the $\mathrm{HCl}$ to aid in coprecipitating. the transplutonium elements in subsequent steps. (All quantities of reagents given in this procedure and on the flowsheets refer to the quantities required per kilogram of rock. Thus, one-fourth of each quantity is added to each bottle.) The reaction 


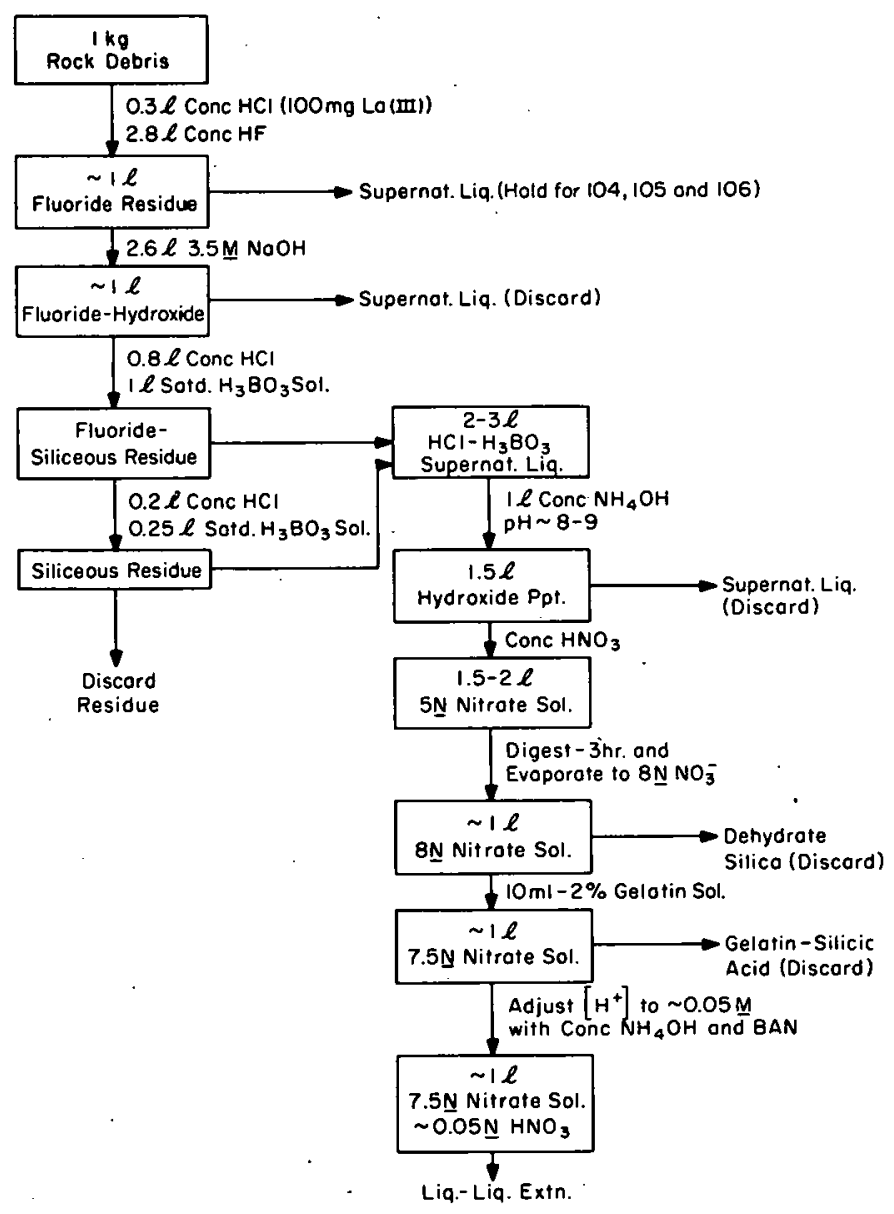

Fig. 6. Flowsheet for Rock Dissolution and Feed Preparation

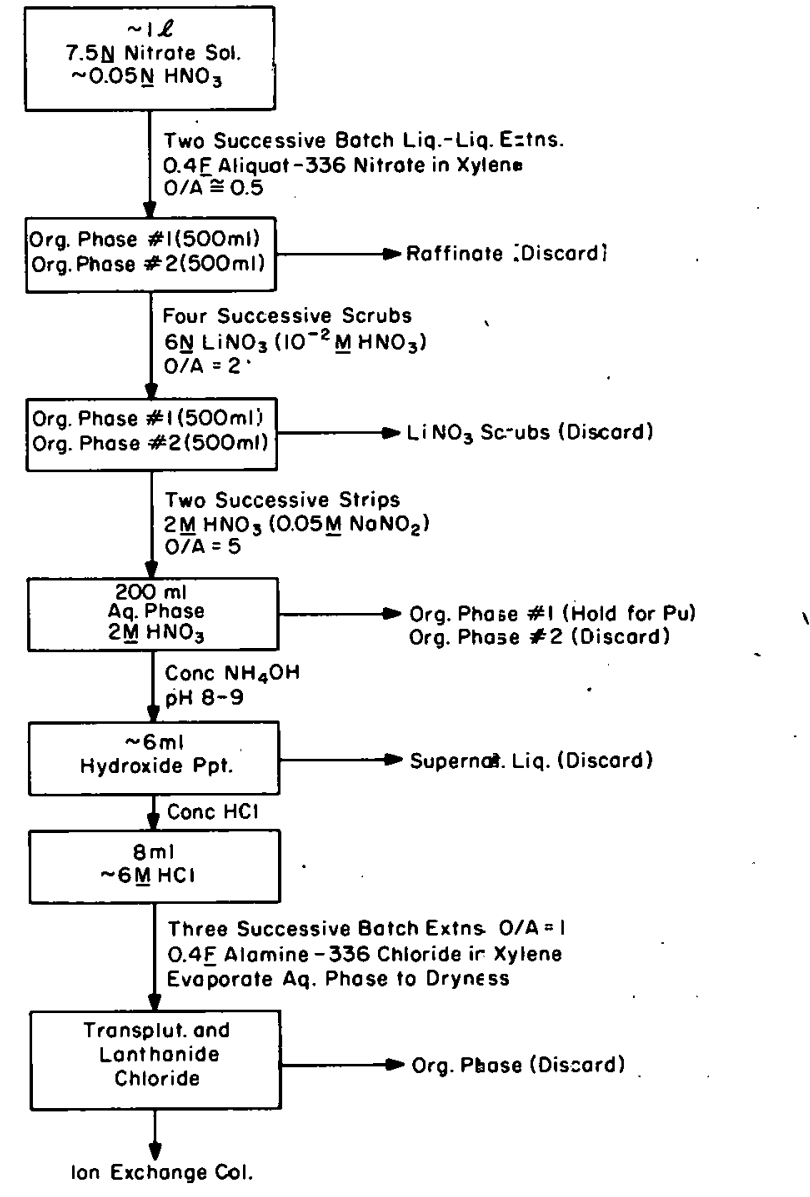

Fig. 7. Flowsheet for LiquidLiquid Extraction Procedure 


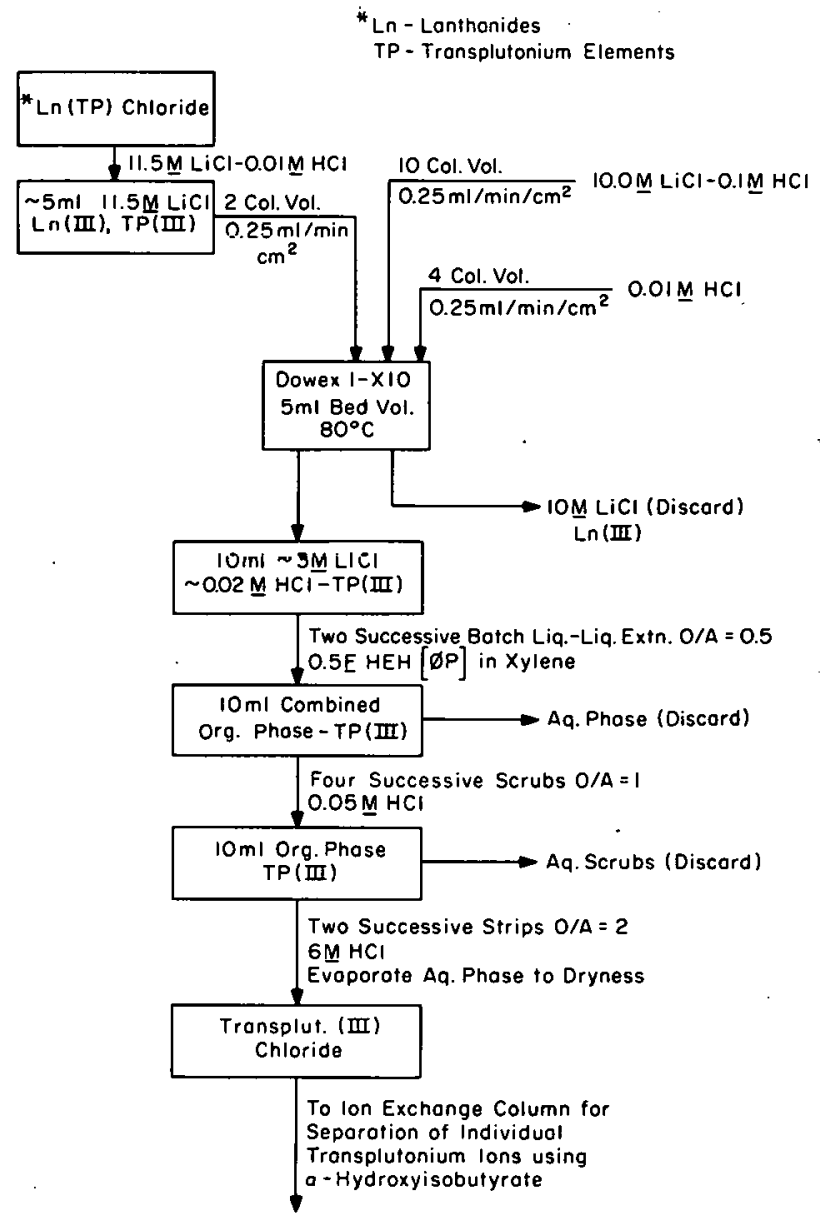

Fig. 8. Flowsheet for the Final Purification of the Trans plutonium Elements

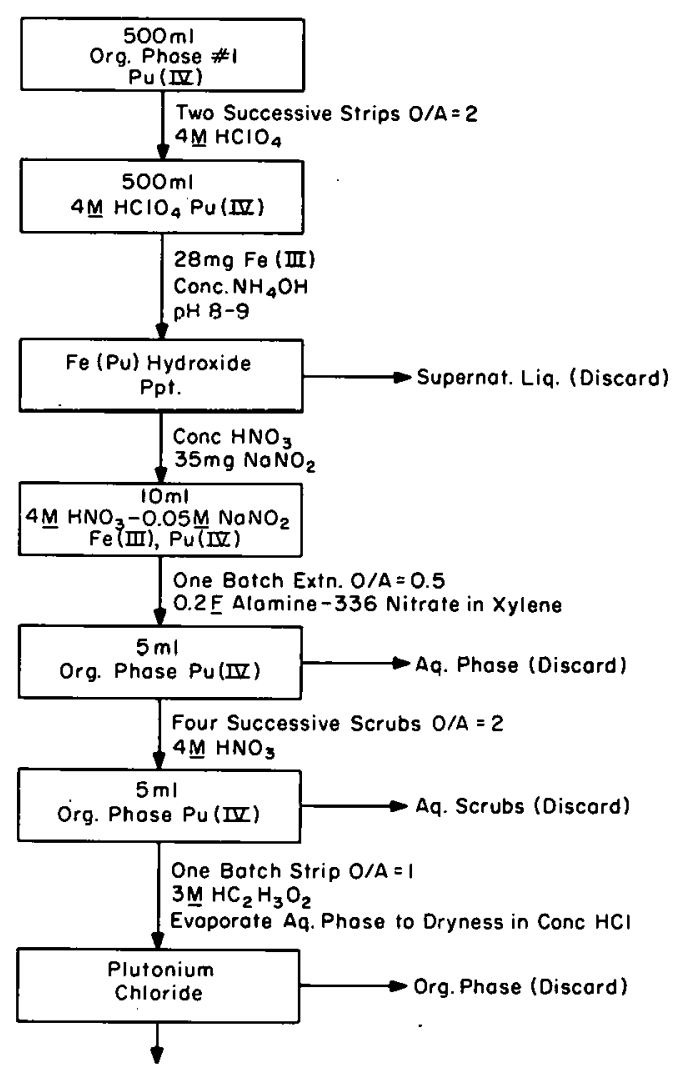

Fig. 9. Flowsheet for the Plutonium Purification

of conc $\mathrm{HF}$ with the pulverized rock is extremely vigorous, evolving $\mathrm{SiF}_{4}$ copiously. The HF solution is added slowly from the plastic reagent bottle while the sample is stirred to prevent the mixture from boiling over. The reaction noticeably subsides upon addition of the final 0.8 liter of HF. The addition of the entire 2.8 liters of HF requires approximately $2 \mathrm{hr}$.

The supernatant liquid is decanted into a waste bottle, and the fluoride residue is washed for 5 min with $500 \mathrm{ml}$ of conc $\mathrm{HF}$ and for $5 \mathrm{~min}$ with 2 liters of $\mathrm{H}_{2} \mathrm{O}$. (These steps are not shown in the Fig. 6 flowsheet.) All solid-liquid mixtures are separated by centrifugation and decantation as described in Section B above. '

Greater than $95 \%$ of the lanthanides and actinides remain in the fluoride residue. The supernatant liquid is essentially a $\mathrm{H}_{2} \mathrm{SiF}_{6}-\mathrm{HF}$ solution containing some $\mathrm{Fe}$ (III) and aluminum. Approximately $90 \%$ or 
more of the fission product $\mathrm{Zr}$ and $\mathrm{Nb}$, together with other fluoride soluble ions, are found in the supernatant liquid.*

The actinides and lanthanides, together with the major cationic constituents of the rock, are dissolved from the fluoride residue by metathesizing the solid phase with $\mathrm{NaOH}$ solution followed by two successive equilibrations of the resultant precipitate with. $\mathrm{HCl}-\mathrm{H}_{3} \mathrm{BO}_{3}$ solution. (see Fig. 6.flowsheet). Approximately $15 \mathrm{~min}$ are allowed for the metathesis reaction, $5 \mathrm{~min}$ for a 3 -liter $\mathrm{H}_{2} \mathrm{O}$ wash (not shown in the $\mathrm{Fig}$ : 6 flowsheet), and $15 \mathrm{~min}$ each for the $\mathrm{HCl}-\mathrm{H}_{3} \mathrm{BO}_{3}$ equilibrations. The $\mathrm{HCl}-\mathrm{B}_{3} \mathrm{BO}_{3}$ supernatant liquid is decanted into four new polypropylene bottles. This solution $(\sim 2.5$ liters $)$ contains approximately $99 \%$ of the actinides and lanthanides present in the fluoride residue.

The effectiveness of this step may be ascertained during processing by measuring the $\beta-\gamma$ activity of the siliceous residue remaining after the final centrifugation and decantation. For example, in an actual processing $r$ un of $1 \mathrm{~kg}$ of radioactive rock debris, the $\beta-\gamma$ activity of the precipitate was $\sim 200 \mathrm{R} / \mathrm{hr}$ at 2 in. before the $\mathrm{HCl}-\mathrm{H}_{3} \mathrm{BO}_{3}$ equilibrations and $\sim 0.6 \mathrm{R} / \mathrm{hr}$ at. 2 in. after. the equilibrations.

\section{Feed Preparation}

The nitrate feed solution is prepared by adding an excess of conc $\mathrm{NH}_{4} \mathrm{OH}$ to the $\mathrm{HCl}-\mathrm{H}_{3} \mathrm{BO}_{3}$ solution ( $\mathrm{pH} \sim 9$ ), washing the resultant precipitate with 1. liter of $\mathrm{H}_{2} \mathrm{O}$ for $5 \mathrm{~min}$ (not shown in flowsheet), and dissolving the hydroxide precipitate in a minimum volume of conc $\mathrm{HNO}_{3}$. (The $\mathrm{pH}$ is estimated with indicator paper.). This step removes a large fraction of the fluoride ion and excess boric acid from the feed solution.

The resultant yellow nitrate solution (1.5-2 liters) (which is cloudy in appearance due to the presence of colloidal silicic acid) is transferred to the 4-liter beaker in containment box 2 . The $\left[\mathrm{NO}_{3}^{-}\right]$of the feed solution is determined (within $\pm 5 \%$ ) by removing a $100-\mu 1$ aliquot, rinsing the aliquot through a $5-\mathrm{ml}$ bed volume ion-exchange column (Dowex 50-X8) on the hydrogen ion cycle, and titrating the eluate $\left(\mathrm{HNO}_{3}\right.$ ) with a standard solution of $\mathrm{NaOH}$. The $\left[\mathrm{NO}_{3}^{-}\right]$of this solution is usually $\sim 5 \mathrm{~N}$. From the results of this assay, a calculation is made to determine the amount of evaporation of the nitrate solution that is required to raise the $\left[\mathrm{NO}_{3}^{-}\right]$to $\sim 8 \underline{\mathrm{N}}$. The nitrate solution. is then digested for $3 \mathrm{hr}$ and simultaneously evaporated to the calculated volume ( l. liter). During

*It is believed that elements 104,105 , and 106, if present, would also be found in the HF supernatant liquid. Experiments using small quantities of rock containing tracer $\mathrm{Hf}, \mathrm{Ta}$, and $\mathrm{W}$, which are the possible congeners of elements 104, 105, and 106, respectively, show that greater than $90 \%$ of each of these elements is found in the HF supernatant liquid. ${ }^{8}$ 
the digestion, a large fraction of the colloidal silicic acid dehydrates and settles out of solution as an amorphous blob. Upon completion of the digestion and evaporation, the mixture is returned to the four centrifuge bottles. The dehydrated silicic acid is separated by centrifugation and washed successively with equal volumes $(\sim 100 \mathrm{ml})$ of $6 \mathrm{~N} \mathrm{LiNO}_{3}-10^{-2} \mathrm{M}$ $\mathrm{HNO}_{3}$ and $0.1 \mathrm{M} \mathrm{HNO}_{3}$. (Washing steps are not shown in the Fig. 6 flowsheet.) The washings are combined with the l liter of supernatant nitrate solution. This solution is usually clear but still contains soluble silicic acid. The remaining silicic acid is flocculated by the addition of $10 \mathrm{ml}$ of $2 \%$ gelatin to the nitrate solution, followed by $5-10 \mathrm{~min}$ stirring. The floc $(\sim 60 \mathrm{ml})$ is separated from the nitrate solution by first centrifuging the mixture and then gravity-filtering the contents through a coarsesintered glass funnel. The precipitate is washed successively with equal volumes of $6 \mathrm{M} \mathrm{LiNO}-10^{-2} \mathrm{M} \mathrm{HNO}_{3}$ and $0.1 \mathrm{M} \mathrm{HNO}_{3}$. (Washing steps are not shown in the Fig. 6 flowsheet.)

Small-scale experiments with rock debris containing known quantities of tracer ${ }^{239} \mathrm{Pu},{ }^{242} \mathrm{Cm}$, and ${ }^{252} \mathrm{Cf}$ have shown the following losses in activity during the silicic acid removal steps:

\begin{tabular}{lcc} 
& $\begin{array}{c}\text { Precentage of Total Activity. } \\
\text { in Dehydrated Silicic } \\
\text { Acid Precipitate }\end{array}$ & $\begin{array}{c}\text { Percentage of Total Activity } \\
\text { in Gelatin-Silicic } \\
\text { - Acid Precipitate }\end{array}$ \\
\cline { 2 - 3 }${ }^{239} \mathrm{Pu}$ & 0.5 & 0.3 \\
${ }^{242} \mathrm{Cm}$ & 0.6 & 0.3 \\
${ }^{252} \mathrm{Cf}$ & 0.5 & 0.3
\end{tabular}

The $\left[\mathrm{H}^{+}\right]$concentration of the resultant silica-free nitrate solution ( l liter and contained in the 4-liter beaker) is measured approximately by removing a $100-\mu \mathrm{l}$ aliquot, diluting the aliquot to $10.0 \mathrm{ml}$ in a volumetric flask, and measuring the $\mathrm{pH}$ of the diluted solution. The $\left[\mathrm{H}^{+}\right]$ of the concentrated nitrate solution is determined from the $\mathrm{pH}$ measurement by using an empirical activity coefficient of 0.7 and the dilution factor of the aliquot. The calculated quantity of conc $\mathrm{NH}_{4} \mathrm{OH}$ required to bring the $\mathrm{H}^{+}$concentration to $0.1 \mathrm{M}$, is added followed by final adjustment to 0.03-0.07 $\mathrm{M} \mathrm{H}^{+}$by addition of basic aluminum nitrate (BAN).* The BAN is $2.5 \mathrm{M}$ in aluminum and $1.0 \mathrm{M}$ in base.

*A low $\left[\mathrm{H}^{+}\right]$in the feed solution is important in order to get a high recovery $(>99 \%)$ of the transplutonium(III) ions in the liquid-liquid extraction step. If, however, the $\left[\mathrm{H}^{+}\right]$is made less than $\sim 0.01 \underline{\mathrm{M}}$, then $\mathrm{Fe}$ (III) will begin to precipitate. On the other hand if the $\left[\mathrm{H}^{+}\right]$is $0.1 \mathrm{M}$ or higher, more than two batch extractions will be required to obtain a high recovery. The extractant will remove excess $\mathrm{HNO}_{3}$, but, in so doing, will lower the $\mathrm{K}_{\mathrm{d}}$ for the transplutonium(III) ions. ${ }^{6}$ 
A typical composition of the nitrate feed is the following:

$$
\begin{aligned}
\mathrm{Al}(\mathrm{III}) & =1.8 \underline{\mathrm{M}} \\
\mathrm{Ca}(\mathrm{II}) & =0.6 \underline{\mathrm{M}} \\
\mathrm{Mg}(\mathrm{II}) & =0.15 \underline{\mathrm{M}} \\
\mathrm{Fe}(\mathrm{III}) & =0.001 \underline{\mathrm{M}} \\
\mathrm{H}_{3} \mathrm{BO}_{3} & =0.4 \underline{\mathrm{M}} \\
\mathrm{NH}_{4}^{+} & =0.6 \underline{\mathrm{M}} \\
\text { Total NO} & =7.5 \underline{\mathrm{M}} \\
\mathrm{H}^{+} & =0.05 \underline{\mathrm{M}} \\
\text { Volume } & =1.2 \text { liters }
\end{aligned}
$$

In addition, the feed solution contains an undetermined concentration of fluoride, probably in the range of 0.1 to $0.5 \mathrm{M}$.

\section{Liquid-Liquid Extraction}

The feed solution is equilibrated twice successively with $\sim 500-\mathrm{ml}$ portions of $0.4 \mathrm{~F}$ Aliquat -336 nitrate in xylene. The equilibration time is $\sim 4 \mathrm{~min}$, and the breaking time of the phases is $\sim 1 \mathrm{~min}$. The raffinate is discarded. The two batch equilibrations remove $>99 \%$ of the plutonium and transplutonium elements. In addition, a large fraction of the lanthanide elements and $F$ (III) present in the feed are also extracted into the organic phases.

The organic phases are scrubbed with $6 \underline{\mathrm{M}} \mathrm{LiNO}_{3}-10^{-2} \underline{\mathrm{M}} \mathrm{HNO}_{3}$ for additional decontamination from $\mathrm{Al}, \mathrm{Ca}, \mathrm{Mg}, \mathrm{Fe}, \mathrm{Zr}, \mathrm{Nb}$, and $\mathrm{Sr}$. Each $\mathrm{LiNO}_{3}$ scrub is equilibrated for $4 \mathrm{~min}$, first with organic phase No. 1 and then with organic phase No. 2. The breaking time of the phases is $<40$ sec. Less than $0.1 \%$ of the plutonium and transplutonium ions are back-extracted during the scrubbing operation.

The transplutonium(III) ions are stripped from the organic phase with $2 \mathrm{M} \mathrm{HNO}_{3}-0.05 \mathrm{M} \mathrm{NaNO}_{2}$ * Each portion of $\mathrm{HNO}_{3}$ solution is equilibrated for $4 \mathrm{~min}$, first with organic phase No. 2 and then with organic phase No. 1. Breaking times are $<30 \mathrm{sec}$. The strip solutions are combined $(\sim 200 \mathrm{ml})$ and scrubbed with an equal volume of xylene to remove any residual organic phase (not shown in the Fig. 7 flowsheet). Approximately $99.9 \%$ of the transplutonium elements and only $0.5 \%$ of the plutonium are stripped from the organic phase. Organic phase No. 1 contains $98 \%$ of the total plutonium extracted and therefore is held for plutonium recovery (Step 5). Organic phase No. 2 is discarded.

\footnotetext{
*The purpose of the $\mathrm{NaNO}_{2}$ in the strip solution is to maintain the plutonium ions in the highly extractable +4 oxidation state. This prevents any back-extraction of $\mathrm{Pu}(\mathrm{III})$ or $\mathrm{Pu}(\mathrm{VI})$.
} 
The total recovery of the transplutonium elements and lanthanum carrier in the liquid-liquid extraction step is $\sim 99 \%$. This is assuming that thc phases are separated in such a way as to minimize loss of the particular phase containing the product. Spectrochemical analyses of the $\mathrm{HNO}_{3}$ solution show decontamination factors, with respect to the transplutonium elements or lanthanum carrier, of $>10^{4}$ for aluminum and magnesium, $\sim 10^{4}$ for calcium, and $\sim 20$ for iron. The $\beta-\gamma$ activity of the solution, which is almost entirely due to lanthanide fission products, is approximately $\mathrm{l}-5 \mathrm{R} / \mathrm{hr}$ at 2 in.

At this stage, the transplutonium fraction is transferred from the high-level cave to a laboratory hood for final processing.

\section{Final Purification of the Transplutonium Elements}

The transplutonium elements are rapidly. concentrated and decontaminated further by coprecipitating on lanthanum hydroxide (which was added in Step 1), dissolving the hydroxide precipitate $(\sim 6 \mathrm{ml})$ in conc $\mathrm{HCl}$, and equilibrating the resultant $\mathrm{HCl}$ solution $(\sim 8 \mathrm{ml})$ with $0.4 \mathrm{~F}$ Alamine- 336 chloride in xylene (see Fig. 8 flowsheet). The extractant, a tertiary amine hydrochloride, removes the last traces of $\mathrm{Mn}, \mathrm{Fe}, \mathrm{Co}$, $\mathrm{Cu}, \mathrm{Zn}, \mathrm{Cd}, \mathrm{Hg}, \mathrm{Pd}, \mathrm{Zr}, \mathrm{Nb}, \mathrm{Mo}, \mathrm{Tc}, \mathrm{U}, \mathrm{Np}$, and $\mathrm{Pu}$ that may be present in the aqueous phase ( $\mathrm{Fe}$ (III) is usually visibly present). The loss of transplutonium elements in this step is negligible. The aqueous phase is washed three times successively with an equal volume of xylene to remove any residual organic phase (this step is not shown in the Fig. 8 flowsheet) and then evaporated to dryness. A white, hydrated lanthanide chloride residue forms in the bottom of the tube.

The results of a spectrographic analysis of a lanthanide chloride residue at this stage of the process are the following:

\begin{tabular}{c} 
Percentage of \\
Total Cations \\
in Residue \\
\hline
\end{tabular}

La

$\mathrm{Ce}-\mathrm{Lu}, \mathrm{Y}$

$\mathrm{Ca}$

Al, $\mathrm{Mg}$

Alkali metals

All other cations

and bor on

\section{0}

5- 10

0.5

$<0.01$

Not measured

Below detectability 
The total alpha activity of the sample, which pulse-height analyses showed to be entirely due to the transplutonium elements, was $4 \times 10^{6}$ dis $/ \mathrm{min}$.

The transplutonium elements are separated from the lanthanides and traces of alkaline-earth metals and aluminum by anion-exchange absorption in concentrated. LiCi media." The column conditions are shown in the Fig. 8 flowsheet. The column diameter is $8 \mathrm{~mm}$, the bed volume is $5 \mathrm{ml}$, and the free column volume (which is abbreviated. col. vol.) is $\sim 2 \mathrm{ml}$.

The effectiveness of the 10M LiCl solution in eluting the lanthanides may be ascertained by measuring the $\beta-\gamma$ activity of the eluate fractions. For example, in an actual processing run of $\mathrm{l} \mathrm{kg}$ of rock debris, the $\beta-\gamma$ activity of the eluate fraction was reduced from a maximum of $3 \mathrm{R} / \mathrm{hr}$ at $2 \mathrm{in}$. in the second plus third col. vol. to $\leqslant 0.4 \times 10^{-3} \mathrm{R} / \mathrm{hr}$ at 2 in. in the loth col. vol. Negligible alpha activity was detected in the se fractions. The transplutonium fraction contained $\sim 4 \times 10^{6} \mathrm{dis} / \mathrm{min}$ and $\mathrm{read}$ $<0.4 \times 10^{-3} \mathrm{R} / \mathrm{hr} \beta-\gamma$ at 2 in.

The contamination of the transplutonium fraction by the previous elutrient solution changes the composition of the $0.01 \mathrm{M} H C 1$ solution to $\sim 3 \mathrm{M} \mathrm{LiCl}-0.02 \mathrm{M} \mathrm{HCl}$. The lithium ion, together with any traces of other alkali metal and ammonium ions, are removed by extracting the transplutionium(III) ions from the dilute $\mathrm{HCl}$ solution by using: 2 -ethylhexylphenylphos phoric acid ( $\mathrm{HEH}[\phi \mathrm{P}])$. (See Fig. 8 flowsheet.) Specially prepared high-purity $\mathrm{HCl}$ solutions (see Appendix B) are used. for scrubbing and stripping the organic phase to minimize contamination of the product by adventitious impurities. The $6 \underline{\mathrm{M}} \mathrm{HC} 1$ strip solution, containing the transplutonium elements, is scrubbed twice with 2 -ethylhexanol and three times with xylene to remove any traces of $\mathrm{HEH}[\phi \mathrm{P}]$ from the aqueous phase. (This step is not shown on the flowsheet.). The resultant solution, upon evaporation to dryness, leaves an extremely minute, almost undetectable residue in the bottom of the centrifuge tube. The overall recovery of the transplutonium elements in Step 4 is at least $99 \%$.

At this stage, the individual elements may be separated on a micro ion-exchange column by using $\alpha$-hydroxyisobutyric acid.

\section{Final Purification of the "Plutonium}

The plutonium in organic phase No. 1 is stripped with $4 \underline{\mathrm{M}}$ $\mathrm{HClO}_{4}$, using 4 -min equilibration times. The breaking time of the phases is $<30$ sec. $1 \mathrm{M} . \mathrm{HSO}_{3} \mathrm{NH}_{2 .-}-0.2 \mathrm{M} \mathrm{Fe}\left(\mathrm{SO}_{3} \mathrm{NH}_{2}\right)_{\ddot{2}}$ is also effective in. stripping plutonium from the quaternary ammonium nitrate extractant. However, the recovery of tracer-level concentrations of plutonium in the ferrous sulfamate solution is more time-consuming than its recovery from perchloric acid solution. Two equilibrations with $\mathrm{HC}_{1} \mathrm{O}_{4}{ }^{\prime}\left(\mathrm{O}^{\prime} / \mathrm{A}=2\right)$ remove. $\sim 99 \%$ of the plutonium from the organic phase. 
The plutonium is rapidly concentrated by coprecipitating on $\mathrm{Fe}(\mathrm{OH})_{3}$, dissolving the precipitate in conc $\mathrm{HNO}_{3}$, and extracting with a tertiary ammonium nitrate solution (see Fig. 9 flowsheet). Additional decontamination of the plutonium from $\mathrm{Fe}, \mathrm{Al}, \mathrm{Mg}, \mathrm{Ca}$, lanthanides, and transplutonium elements is obtained by scrubbing the organic phase with $4 \mathrm{MNO}_{3}$. The plutonium is stripped from the tertiary ammonium nitrateextractant with $3 \mathrm{M} \mathrm{HC}_{2} \mathrm{H}_{3} \mathrm{O}_{2}$, and the resultant acetic acid solution is evaporated to dryness in the presence of $\mathrm{HCl}$. An extremely minute residue is found in the tube after evaporation. The plutonium at this stage is sufficiently free of contaminants for mass-spectrometric analyses. If additional decontamination is required, particularly from uranium, an oxidation-reduction cycle using the tertiary ammonium nitrate extractant is carried out. The overall recovcry of plulunium in Step 5 is $\sim 98 \%$.

\section{SUMMARY}

The overall recovery of plutonium and the transplutonium elements obtained by using the procedure described in this report is difficult to determine exactly because of the uncertainty in the initial concentrations of these elements in the rock-debris samples. However, small-scale experiments, where known quantities of ${ }^{239} \mathrm{Pu},{ }^{242} \mathrm{Cm}$, and ${ }^{252} \mathrm{Cf}$ were added to the rock samples, have produced recoveries in the range of $90-95 \%$. Recoveries of plutonium and the transplutonium elements obtainable on a kilogram scale are estimated to be at least this good.

The time required for two individuals to process a $\mathrm{l}-\mathrm{kg}$ sample of rock through Step 3, which requires the use of the high-level cave and the operation of remote control equipment, is in the range of 18 to $24 \mathrm{hr}$, depending on the efficiency of the operators. An additional $8 \mathrm{hr}$ is required to process the sample through Step 4. No time limit is placed on the processing of the plutonium fraction (Step 5). These processing times assume, of course, that all equipment performs properly. 


\section{APPENDIX A}

Equipment and Materials:

\section{Containment Box 1}

a. Construction

(1) Size: $4 \mathrm{ft}$ deep, $6 \mathrm{ft}$ wide, and $4 \mathrm{ft}$ high

(2) Materials

(a) Aluminum floor plate and panels, painted with two coats of Ámercoat No. 33

(b) Lucite wall sheeting

(c) PVC corner and joining ridterials

(d) Unistrut reinforcing

(e) Plywood pallet, painted with fire-resistant paint

(f) . RTV silicone caulking

(g) Urethane gaskets on transfer port and front panel

(h) Interconnecting transfer device

(i) Centrifuge

(3) Boots for manipulators

(a) Upper boot: PVC, 0.012 in. thick

(b) Lower boot: PVC, 0.006 in. thick

(c) Gauntlet: Hyperlon-coated urethane

(4) Double-door transfer porch: $12 \times 12 \times 9$-in. transfer area

(5) Gloves on sides and back of box for decontamination

b. Ventilation for Containment Box 1

(1) Inlet filters: 8-in. diam $\times 6$ in thick; absolute filters (99.95\% efficient)

(2) Exhaust filters: 8-in. diam $\times 6$ in. thick; absolute filters (99.95\% efficient)

(3) Negative pressure as per manometer $=0.250$ in. of water

\section{Apparatus in Containment Box 1}

a. Motorized four-station stirring unit

b. One-quart, widemouthed, polypropylene bottles and bottle gripper

c. Motorized centrifuge loader

d. Berkeley pipetting equipment

e. Miscellaneous, small handtools

f. Balance

g. Chemical-reagent dispensing station

h. International Size 2 centrifuge 
3. External Equipment for Containment Box. 1

a. Manipulation--Cell Interior

(1) Model 8 master-slave manipulators

(2) Extended-reach master-slave manipulator, used for transfers

(3) One-ton capacity crane

(4) Through-wall transfer slide

b. Transport

(1) Radio-controlled "mule" for transport of sample

(2) Robot manipulator for special transfers

c. Utilities

(1) Quick-connect bulkhead and regular fittings with doubleend shut-off

(a) $1 / 4-$ in. ID for gas

(b) $3 / 8-$ in. ID for liquids

(2) Self-storing coil hose for some liquids and gases

(3) $\mathrm{CO}_{2}$ fire-extinguisher system

(4) AC-DC variable electricity

4. Containment Box 2

a. Construction

(1) Size: $4 \mathrm{ft}$ deep, $6 \mathrm{ft}$ wide, and $6 \mathrm{ft}$.high.

(2) Materials (same as containment box l, except for i)

(3), (4), and (5) (Same as containment box 1)

b. Ventilation for Containment Box 2 (same as. for containment box 1)

5. Apparatus in Containment Box 2

a. Separatory funnels, manually operated

b. Hot-plate magnetic stirrer

c. Beṛkeley pipetting equipment

d. Chemical-reagent dispensing station

e. Miscellaneous, small handtools

f Motorized stirrers for separatory funnels

g. Trunnion-mounted beaker

6. External Equipment for Containment Box 2

(Same as for containment box l). 


\section{APPENDIX B \\ Reagent Purification and Preparation}

Lanthanum(III)--Conc $\mathrm{HCl}$

$117 \mathrm{~g}$ of $\mathrm{La}_{2} \mathrm{O}_{3}(99.997 \%)$ are dissolved in $300 \mathrm{ml}$ of conc $\mathrm{HCl}$.

$2 \%$ Gelatin Solution

$2.0 \mathrm{~g}$ of unflavored pure gelatin protein are dissolved in distilled water and diluted to $100 \mathrm{ml}$. The solution is stored no longer than one day before using.

Basic Aluminum Nitrate (BAN), 2.5 $\mathrm{M}$ Al and 1.0ㅆ Basic

187. $\mathrm{g}$ of $\mathrm{Al}\left(\mathrm{NO}_{3}\right)_{3} \therefore 9 \mathrm{H}_{2} \mathrm{O}$ are dis solved in $75 \mathrm{ml}$ of distilled water. The solution is made basic by adding $13 \mathrm{ml}$ of conc $\mathrm{NH}_{4} \mathrm{OH}$, and the resultant mixture is heated and stirred until the precipitate dissolves. After cooling, the solution is diluted to $200 \mathrm{ml}$ with distilled water.

$0.4 \mathrm{~F}$ Aliquat -336 in Xylene

Aliquat-336 chloride is obtained from General Mills, Inc., Kankakee, Illinois. $19 \mathrm{ml}$ of Aliquat-336 chloride, as received, are dissolved in analytical reagent grade xylene and diluted. to l liter. The resultant solution is equilibrated with $2 \underline{\mathrm{M}} \mathrm{HNO}_{3}$, until chloride ion is undetectable in the aqueous phase when tested with $\mathrm{AgNO}_{3}$. The Aliquat-336 nitrate solution is scrubbed with water to remove excess acid and preconditioned.by equilibrating with a half volume of basic aluminum nitrate.

$\underline{6 \mathrm{M} \mathrm{LiNO}_{3}-10^{-2} \underline{\underline{\mathrm{M}}} \mathrm{HNO}_{3}}$

A $\mathrm{LiNO}_{3}$ stock solution $(\sim 8.5 \underline{\mathrm{M}})$ is prepared from reagent-grade $\mathrm{LiNO}_{3}$ and distilled water. The stock solution is slowly passed through a Dowex 1-X:10 resin bed on the nitrate cycle to remove impurities. The eluate is a purified colorless $\mathrm{LiNO}_{3}$ solution. The $6 \underline{\mathrm{M}} \mathrm{LiNO}_{3}-10^{-2} \underline{\mathrm{M}}$ $\mathrm{HNO}_{3}$ solution is prepared from the stock solution by dilution with $\mathrm{H}_{2} \mathrm{O}$ and addition of reagent grade $\mathrm{HNO}_{3}$.

$0.4 \underline{F}$ Alamine -336 Chloride and 0.2E Alamine-336 Nitrate

Alamine-336, a mixture of octyl and decyl tertiary amine, is obtained from General Mills, Inc., Kankakee, Illinois. The tertiary amine is purified by neutralizing one-half of the amine molecules with conc $\mathrm{HCl}$ and separating the resultant two organic phases in a separatory funnel. The bottom layer contains primary and secondary amines and the top layer the purified tertiary amine hydrochloride. The purified.amine hydrochloride was scrubbed successively with equal volumes of $1 \underline{\mathrm{M}} \mathrm{Na}_{2} \mathrm{CO}_{3}$ 
and $\mathrm{H}_{2} \mathrm{O}$ and then subjected to reduced pressure to remove water and volatile impurities. The equivalent weight of the purified Alamine-336 is 407 .

Xylene solutions of the purified Alamine -336 are prepared. by direct weighing of the amine, followed by dilution in a volumetric flask with analytical grade xylene. The Alamine-336 chloride and nitrate are prepared by equilibrating. separate Alamine- -336 solutions twice successively with conc $\mathrm{HCl}$ and $4 \underline{\mathrm{M}} \mathrm{HNO}_{3}$, respectively.

$11.3 \underline{\mathrm{M}} \mathrm{LiCl}-10^{-2} \underline{\mathrm{M}} \mathrm{HCl}$ and $10.0 \underline{\mathrm{M}} \mathrm{I} . \mathrm{iCl}-0.1 \underline{\mathrm{M}} \mathrm{HCl}$

A LiCl stock solution ( $\sim 13 \underline{M})$ is prepared from reagent grade LiCl and column water. * 'l'he stock solution is slowly passed.through a Dowex :1-X10 resin bed on the nitrate cycle to remove impurities. The eluate is a purified, colorless, LiCl solution. Other LiCl solutions are prepared from the stock solution by dilution with $\mathrm{H}_{2} \mathrm{O}$ and addition of reagent grade $\mathrm{HCl}$.

\section{$0.5 \mathrm{~F} H E H[\phi P]$ in Xylene}

The $\mathrm{HEH}[\phi \mathrm{P}]$ is prepared by hydrolyzing. 2-ethylhexylphenyl phosphonate with a $50 \%$ excess of $\mathrm{NaOH}$. The neutral ester is obtained from Victor Chemical Co., Inc., Chicago Heights, Illinois. The mixture of $\mathrm{NaOH}$ and neutral phosphonate ester is equilibrated at $97^{\circ} \mathrm{C}$ for $24 \mathrm{hr}$ in a stainless-steel beaker. The sodium salt of $\mathrm{HEH}[\phi \mathrm{P}]$ is salted out of the mixture of 2 -ethylhexanol and unhydrolyzed ester with an excess of xylene. Additional decontamination of the sodium salt from 2 -ethylhexanol is obtained by scrubbing with xylene. The final $\mathrm{HEH}[\phi \mathrm{P}]$ solution is obtained by scrubbing the sodium salt with $\mathrm{HCl}$ and diluting with xylene. The resultant $\mathrm{HEH}[\phi \mathrm{P}]$ is standardized by titration using standard. $\mathrm{NaOH}$ solution and phenolphthale in indicator.

High-purity $\mathrm{HCl}$ Solutions $(0.01 \underline{\mathrm{M}}, 0.05 \underline{\mathrm{M}}$, and $6 \underline{\underline{\mathrm{M}}})$

A high-purity $\sim 13 \mathrm{M} \mathrm{HCl}$ stock solution is prepared by saturating column water* with pure $\mathrm{HCl}$ gas. The $0.01 \underline{\mathrm{M}}, 0.05 \underline{\mathrm{M}}$, and $6 \underline{\mathrm{M}} \mathrm{HCl}$ solutions are prepared from the stock solution by dilution with column water.

\section{Other Reagents}

The concentrated $\mathrm{HF}(49 \%), \mathrm{HCl}(36.9 \%), \mathrm{HNO}_{3}(70.3 \%)$, and $\mathrm{NH}_{4} \mathrm{OH}(30 \%)$, as well as sodium hydroxide, boric acid, and $\mathrm{NaNO}_{2}$ used in the procedure are reagent grade. The $\mathrm{HC}^{\prime} \mathrm{O}_{4}$ solution is prepared from vacuum-distilled $70 \% \mathrm{HClO}_{4}$.

*Column water is prepared by passing distilled water through a mixedbed ion-exchange column. 


\section{ACKNOW LEDGMENT}

We wish to thank Mr. Herbert Diamond, with whom the authors had many helpful discussions and whose experience with small-scale processing of rock-debris samples contributed to the development of this process. The authors also wish to thank Mr. Walter Podolski for his help in constructing. the containment boxes and assembling the remote-control equipment.

\section{REFERENCES}

1. Dorn, D. W.. "Heavy Ieotope Pruluction by Nuclear Devices," Proceedings of the Third Plowshare Symposium, TID-7695, Vol. I, Davis,. California, April 21-23, 1964; p. 1.l.

2. Annual Report to Congress of the Atomic Energy Commission for 1964 (Jan 1965), p. 164 .

3. Dorn, D. W., and Hoff, R. W., UCRL-123.95 (Feb.10, 1965).

4. Hoff, R. W., and Dorn, D. W., Nucl. Sci. Eng. 18, 110 (1964).

5. Horwitz, E. P., Bloomquist, C. A. A., Sauro, L. J., and Henderson, D. J., J. Inorg. Nucl. Chem. (to be published).

6. Groh, H. J., DP-293. (June 1958).

7. Gatti, R. C., Phillips, L., Sikkeland, T., Muga, M. L., and Thompson, S. G., J. Inorg. Nucl. Chem. 11, 251.(1959).

8. Diamond, Herbert, Argonne National Laboratory, Private Communication.

9. Hulet, E..K., Gutmacher, R. G., and Coops, M. S., J. Inorg, Nucl. Chem: 1.7, 350 (1961). 
